\title{
PRACTICAL ASPECTS OF USE OF PERSPECTIVE ORNAMENTAL PLANTS OF THE GENUS ANEMONE L. FOR THE LANDSCAPING IN FOREST-STEPPE OF UKRAINE
}

\author{
Pereboichuk Oksana
}

M.M. Gryshko National Botanical Garden of NAS of Ukraine, Kyiv, Ukraine

\section{ПРАКТИЧНІ АСПЕКТИ ВИКОРИСТАННЯ ПЕРСПЕКТИВНИХ ДЛЯ ОЗЕЛЕНЕННЯ КВІТНИКОВО-ДЕКОРАТИВНИХ РОСЛИН РОДУ АNEMONE L. В УМОВАХ ЛІСОСТЕПУ УКРАЇНИ}

\section{Перебойчук Оксона}

Received 22. 6. 2017

Revised 26.6. 2017
Published 29. 11. 2017

The results of the introduction of decorative taxons of the genus Anemone L. in Forest-Steppe of Ukraine are represented in this article. On the basis of scientific principles, the main options for combining them in landscape compositions have been developed. Behind the life form of plants, taxa were grouped into a five groups: plants with long rhizomes and single flowers, ephemeroids (Anemone altaica Fisch. ex Ledeb., Anemone nemorosa L., Anemone ranunculoides L.); tuberous rhizomes (Anemone blanda Schott \& Kotschy); with vertical caudexes and a taproot, or a mixed root system (Anemone multifida Poir., Anemone narcissiflora L., Anemone rivularis Wall., Anemone rivularis var. flore-minore Maxim.); roots sprouts Anemone (Anemone canadensis L., Anemone dichotoma L., Anemone hupehensis Hort. Ex Boynton, Anemone hupehensis var. japonica (Thunb.) Bowles \& Stearn, Anemone sylvestris L., Anemone tomentosa (Maxim.) S.F. Pei); with a fibrous root system (Anemone cylindrica A.Gray, Anemone virginiana L., Anemone virginiana var. alba (Oakes) Alph.Wood.). By selected groups were analyzed their potential growth opportunities, the formation of habit and offered posibilities of use in the landscape under the conditions of the Forest-Steppe of Ukraine. Anemone are more attractive when used in the landscape style. The assortment of taxons is developed for various elements of floral-decorative design: single plantings, group plantings, single-species groupings, rock gardens, mixboxers, rabatte, landscaping around a water basins, single species gardens, natural garden, garden cognitive compositions etc. Thus, the use of plants of the Anemone species for the gardening in the conditions of the Forest-steppe of Ukraine will enable enrichment of the taxonomic assortment of flower-decorative plants and expand the opportunities for the formation of diverse, durable, highly decorative landscape compositions.

Keywords: ornamental herbaceous plants; Anemone; landscape compositions; gardening; floriculture; life form of plants

\footnotetext{
*Corresponding author: Oksana Pereboichuk, M.M. Gryshko National Botanical Garden of NAS of Ukraine,
} Kyiv, Ukraine, $\bowtie$ fiorgy@meta.ua 


\section{Вступ}

Одним із шляхів вирішення проблеми покращення стану навколишнього середовища урбанізованих територій $є$ формування стійких міських біогеоценозів. Ефективність у поєднанні з високою декоративністю штучних насаджень передусім залежить від різноманітності і правильного підбору асортименту рослин в залежності від їх біоекологічних особливостей та функціонального призначення об'єктів. Тому вивчення питань щодо збагачення і оновлення асортименту перспективних для озеленення видів та культиварів, розробки варіантів їх використання і на сьогодні залишаються актуальними.

При створенні і реконструкції зелених насаджень, у тому числі й м. Києва, здебільшого приділяється увага деревам та кущам. Декоративні трав'янисті рослини використовуються в незначній кількості для часткового квітникового оформлення міста і практично не включаються в цілісні архітектурно-ландшафтні композиції. При цьому асортимент їх досить одноманітний і базується переважно на однорічних культурах.

Перші відомості про використання в декоративному садівництві більшості трав'янистих багаторічників датуються XV - XVI ст., проте значна частина із них і сьогодні залишається малопоширеною, чи й зовсім не використовується в культурі. Одними з таких $\epsilon$ і представники роду Anemone L. Рекомендації про їх використання наводяться в класичній роботі для садівників J. Parkinson 'Paradisi in Sole Paradisus Terrestris' (Parkinson, 1904), де описано два види (Anemone coronaria, Anemone pavonina) та 30 їх культиварів, серед яких і гібриди з махровими квітками. На сьогодні таксони цього роду досить широко представлені у світовому асортименті (Index, 1994; Royal, 1996; Mclndoe, 2005; Музичук, 2009), та є високоперспективними для озеленення в Україні, проте їх практично не використовують, трапляються вони здебільшого серед квітникарів-аматорів (Музичук, 2009; Музичук, 2013).

Садову цінність цих рослин визначає як природно притаманна їм висока декоративність, так і обумовлене їхньою широкою біологічною, зокрема, і екологічною диференціацією, багатство за формою, розмірами, строками цвітіння, різноманітністю геліо-, гідро- та трофоморф. Їх висока привабливість для практичного використання полягає і в тому, що саме ці види здатні забезпечувати барвами свого рясного цвітіння ранньо- та пізньовесняний (березень-травень), частково весняно-літній (травень-червень), та літньо-осінній (кінець серпня-жовтень) періоди, для яких асортимент квітникових рослин не такий багатий, як для літнього сезону.

\section{Матеріали та методи}

3 метою більш широкого ідоцільного використання в озелененні представників роду Anemone на основі науковихзасадрозроблено основні варіантиїх комбінуваннявландшафтних композиціях. Для роботи використовувались успішно інтродуковані в Національному ботанічному саду ім. М.М. Гришка НАНУ таксони роду Anemone, які за результатами проведеної нами оцінки успішності інтродукції за комплексом господарсько-біологічних показників виявились високоперспективними чи перспективними для широкого використання в декоративному садівництві (Перебойчук, 2013): Anemone altaica Fisch. ex Ledeb., Anemone blanda Schott \& Kotschy, Anemone canadensis L., Anemone cylindrica A.Gray, Anemone dichotoma L., Anemone hupehensis Hort. Ex Boynton, Anemone hupehensis var. japonica (Thunb.) Bowles \& Stearn, Anemone multifida Poir., Anemone narcissiflora L., Anemone nemorosa L., Anemone ranunculoides L., Anemone rivularis Wall., Anemone rivularis var. flore-minore Maxim., Anemone sylvestris L., Anemone tomentosa (Maxim.) S.F. Pei, Anemone virginiana L., Anemone virginiana var. alba (Oakes) Alph.Wood.

\section{Результати та їх обговорення}

Перспективні для озеленення види роду Anemone представлені різними феноритмотипами та екотипами, що дає змогу багатоманітного їх використання в ландшафтному оформленні 
різноманітних об'єктів. Привабливість цих рослин зумовлена ще й тим, що більшість із них придатні для подвійного застосування, не тільки у квітниках, а й для підвищення естетичної привабливості великих масивів різних типів ландшафту, зокрема тінистих місць парків.

Рослини природної флори, до яких належать і таксони роду Anemone, більш органічні при використанні в декоративному садівництві в пейзажному стилі, головний принцип якого природність. При підборі можливих варіантів їх використання (табл. 1) перш за все звертали увагу на життєву форму рослин, яка вказує на особливість розростання особин та на їх феноритмотип. За цими ознаками рекомендовані для озеленення нами види поділяються на: рослини з довгими кореневищами й поодинокими квітками, ефемероїди; із бульбо подібними кореневищами; із вертикальним каудексом і стрижневою, або змішаною кореневою системою; кореневопаросткові анемони; із мичкуватою кореневою системою.

Таблиця 1 Варіанти використання досліджуваних видів роду Anemone L. у озелененні

Table 1 Variants of the use of the studied species of the genus Anemone L. in the landscaping

\begin{tabular}{|c|c|c|c|c|c|c|c|c|c|}
\hline \multirow[t]{2}{*}{ Вид } & \multicolumn{9}{|c|}{ Елементи квітково-декоративного оформлення } \\
\hline & 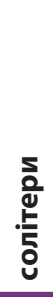 & 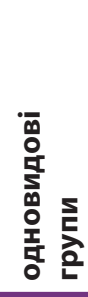 & 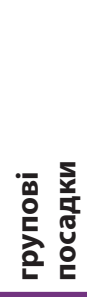 & 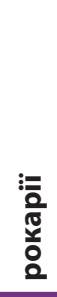 & 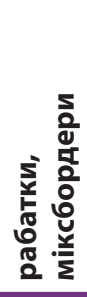 & 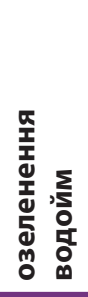 & 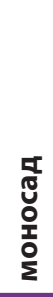 & 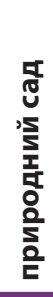 & 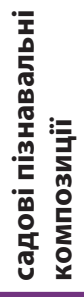 \\
\hline A. altaica & - & - & + & - & + & - & + & + & + \\
\hline A. blanda & - & - & + & + & + & - & + & + & + \\
\hline A. canadensis & - & + & + & - & + & + & + & + & + \\
\hline A. cylindrica & - & - & + & - & + & + & + & + & + \\
\hline A. dichotoma & - & + & + & - & + & + & + & + & + \\
\hline A. hupehensis & + & + & + & - & + & + & + & + & + \\
\hline A. hupehensis var. japonica & + & + & + & - & + & + & + & + & + \\
\hline A. multifida & - & + & + & + & + & - & + & + & + \\
\hline A. narcissiflora & - & - & + & + & + & - & + & + & + \\
\hline A. nemorosa & - & - & + & - & + & - & + & + & + \\
\hline A. ranunculoides & - & - & + & - & + & - & + & + & + \\
\hline A. rivularis & - & + & + & + & + & + & + & + & + \\
\hline A. rivularis var. flore-minore & - & + & + & + & + & + & + & + & + \\
\hline A. sylvestris & - & + & + & + & + & + & + & + & + \\
\hline A. tomentosa & + & + & + & - & + & + & + & + & + \\
\hline A. virginiana & - & - & + & - & + & + & + & + & + \\
\hline A. virginiana var. alba & - & - & + & - & + & + & + & + & + \\
\hline
\end{tabular}


До першої групи належать рослини (Anemone altaica, Anemone nemorosa, Anemone ranunculoides), які у природі трапляються у широколистяних лісах помірної зони, це ранньовесняно- та весняноквітучі види. Вони розширюють асортимент ранньоквітучих рослин і можуть становити альтернативу ранньоквітучим цибулинним культурам та гармонічно доповнювати їх. Особливість цих видів у тому, що вони не ростуть окремими особинами, а формують куртини та зарослі без чітких границь, інтенсивно захоплюють нові території. Тому їх доцільно використовувати в квітниках ландшафтного стилю, у групових посадках, міксбордерах, садах природного стилю, враховуючи те, що вони декоративні лише у період цвітіння. Особлива цінність цих видів ще й у тому, що вони чудово ростуть у затінку листяних дерев, де в період цвітіння отримують достатню кількість сонячного світла.

Із бульбоподібних видів найбільш перспективна для вирощування в умовах Лісостепу Anemone blanda. Бульбокореневі види анемон найбільш придатні для вирощування в рокаріях, оскільки вони достатньо посухостійкі й світлолюбні.

Біологічна особливість таксонів зі стрижневою кореневою системою - компактність, повільне розростання і декоративна стабільність (Anemone multifida, Anemone narcissiflora, Anemone rivularis, Anemone rivularis var. flore-minore). Вони ефектно виглядають як у полі-, так і в монокомпозиціях. Їх можна використовувати навіть у строгих квітниках регулярного стилю.

Цінність кореневопаросткових анемон (Anemone canadensis, Anemone dichotoma, Anemone hupehensis, Anemone hupehensis var. japonica, Anemone sylvestris, Anemone tomentosa) у тому, що вони утворюють стійкі густі зарості як на сонячних ділянках, так і в напівтіні, у тіні зменшується інтенсивність їх цвітіння. Покрив із цих рослин декоративний із весни до пізньої осені. Тому їх можна висаджувати одновидовими групами. При деяких штучних обмеженнях кореневої системи рослини можна використовувати як солітери, вони будуть чудово акцентувати на собі увагу.

Компактні види із мичкуватою кореневою системою - гості Північно-Американського континенту (Anemone cylindrica, Anemone virginiana, Anemone virginiana var. alba) $є$ не такими яскравими, як інші представники роду, проте їх компактний циліндричний габітус дозволяє використовувати рослини в групових посадках, міксбордерах, у садах природного стилю.

Сукупне тривале цвітіння інтродукованих нами таксонів (Перебойчук, 2013) 3 ранньої весни й до пізньої осені дає можливість створювати моносади неперервного цвітіння роду Anemone та успішно залучати їх для створення змішаних садів неперервного цвітіння.

У навчальних закладах, ботанічних садах, парках відпочинку доцільно залучати рослини цього роду для створення садових композицій які несуть також і пізнавальне навантаження: сезонне, географічне, біологічне, екологічне.

\section{Висновки}

Використання таксонів роду Anemone для озеленення в умовах Лісостепу України дозволить збагатити таксономічний склад асортименту квітково-декоративних рослин та розширить можливості при формуванні різнопланових, довговічних, високодекоративних ландшафтних композицій.

\section{Література}

Index of garden plants. 1994. Portland: Timber Press. 1234 p. ISBN 0-88192-246-3.

Mclndoe, A., Hobbs, K. 2005. Herbaceous perennials: The Hillier gardener's guides. London: David \& Charles, 160 p. ISBN 978-0-7153-2024-2.

Parkinson, J. 1904. Paradisi in Sole Paradisus Terrestris (1629). London: Methuen \& co. 656 p. 
Royal Horticultural Society A-Z Encyclopedia of Garden Plants. 1996. London: New York, Stuttgart, Moskow: Dorling Kindersley, 576 p. ISBN 0-7513-0436-0.

Музичук, Г., Перебойчук, О. 2009. Квітниково-декоративні рослини роду Anemone L. у культи генній флорі світу та перспективи їх інтродукції в Україну. Інтродукція рослин, № 4, с. 29-41.

Музичук, Г., Перебойчук, О. 2013. Морфологічні та екологічні особливості, перспективи інтродукції і досліджень квітниково-декоративних рослин роду Anemone L. в умовах Полісся і Лісостепу України. Інтродукція рослин, №1, с. 62-72.

Перебойчук, О. 2013. Итоги интродукции декоративных растений рода Anemone L. в условиях Полесья и Лесостепи Украины. Цветоводство традиции и современность: материалы VI Междунар. науч. конф. (Волгоград, 15-18 мая 2013 г.). Белгород: ИД «Белгород» НИУ «БелГУ», с. 125-128. 